\title{
Experiences of Physically Disabled Women during Childbirth. A Systematic Review of the Latest Literature
}

\author{
Aikaterini PAVLIDOU, Antigoni SARANTAKI \\ Department of Midwifery, University of West Attica, Athens, Greece
}

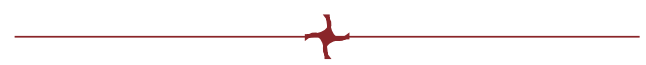

\begin{abstract}
Background: The aim of this systematic review was to elucidate the thoughts, needs, feelings and barriers that women with physical disabilities face during childbirth. The review is based on studies including testimonies of women who described their delivery experiences. The systematic research was conducted using two online bibliographic databases.

Methods: The review considered all types of studies relevant to the theme that were written in English and were published from 2016 to February 2021. In total, 89 studies that were assessed through the PubMed and Google Scholar databases were collected.

Results: Only six of the 89 studies met the inclusion criteria and were deemed valid. Our findings showed that the components that define labour experiences of women with physically disabling conditions were selection of type of birth and anaesthesia, inexperience and lack of knowledge of clinicians surrounding disabilities, negative attitudes of medical staff, non-cooperation between healthcare settings of clinicians, inadequate equipment and facilities, and absence of a birth plan.

Conclusion: Health professionals ought to overcome these obstacles, in order to achieve improved mother and infant outcomes. This could be achieved through the suggested further research, review of publications, improvement of facilities, and through cultivation of professionalism, respect, and empathy with regards to clinicians' attitudes towards these women and this vital period in their life.
\end{abstract}

Keywords: physical disability, childbirth, perinatal experiences, physically disabled pregnant, disability and maternity.

\section{BACKGROUND}

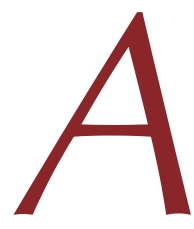

$t$ the outset of this research about the patient population considered in this review, a robust definition of disability deemed essential was used. According to the $\operatorname{CDC}(1)$, a disability is "any condition of the body or mind (impairment) that makes it more difficult for the person with the condition to do certain activities (activity limitation) and interact with the world around them (participation restrictions)". There are many categories of disabilities, with the most well-known of them being physical disabilities (1). These appear

\footnotetext{
Address for correspondence:

Dr. Antigoni Sarantaki

Midwifery Department, University of West Attica, Egaleo, Athens-Greece

Land line: +30 2105387403 ORCID ID: https://orcid.org/0000-0003-3316-8566

Email: sarantaki.antigoni@gmail.gr
} 
either for congenital/hereditary reasons (e.g., since birth, later as a result of genetic factors, due to muscle cell problems, or birth injury), or acquired, due to accident, infection, disease or development of a disorder. In addition, this category is divided into two subgroups: 1) Musculoskeletal disability; and 2) Neuromuscular disability. The former refers to issues in action and movement due to deformities of the bones and muscles. This includes physical disabilities such as the loss/deformity of limbs, osteogenesis imperfecta and muscular dystrophy. The second subgroup regards a person's inability to regulate his/her movements due to issues of the nervous system and includes physical disabilities such as cerebral palsy, spina bifida, poliomyelitis, stroke, head injury and spinal cord injuries (2).

Life with a physical disability may seem unusual and an impossible task for many able-bodied people. In contrast, many people that live with physical disabilities are able to perform all of the activities of daily life, including shopping, work, education and having a family. Many able-bodied people may assume that women who experience the stigma surrounding a physical impairment may not have the desire to become mothers. However, it is essential to accept the fact that every woman has the right to have a child if she wishes to, irrespective of having a disability or not. According to the World Health Organization, $10 \%$ of women with a disability worldwide are of childbearing age (3). Also, in the United States, it has been found that women with physical disabilities give birth at similar rates to non-disabled women (4).

Although people that live with disabilities are accustomed to a special form of lifestyle and are able to face daily barriers, becoming a parent is an unprecedented and complex process for all people, and requires specific psychological management and support from the family and medical environment. Despite this, there is insufficient information about the transition to motherhood for women with physical disabilities $(3,5,6)$, regarding their thoughts, feelings, needs and holistic perinatal care. All available statistics indicate that there is an imperative need for health professionals to address this patient population with more advanced attention than the non-disabled population, in order to ensure positive labour experiences for these women, their infants and their families.
In this article, we summarise the perinatal experiences of women with physical disabilities who have described the delivery of their children, and discuss the favourable and adverse conditions they faced during that period of time (3-7). Recommendations from these women to health professionals are also included, in order to eliminate the barriers that this patient population encounters during childbirth (5). The experiences discussed in this article outline topics such as knowledge about individualised management of labour (3-7) and anaesthesia processes $(3,5)$, attitudes $(4,7)$, communication (4), consultancy and planning of birth (4), collaboration among obstetricians and other maternity care providers $(4,6)$ and equipment issues $(4)$.

\section{Aim}

The aim of this review based on the most recent available data is to describe the thoughts, feelings, needs and barriers that women with physical disabilities experience during childbirth using a general framework.

\section{METHODS}

\section{iterature search strategy}

— The studies used in this article were gathered after conduction of a systematic search of two medical electronic bibliographic databases, PubMed and Google Scholar, between February 2021 and May 2021. The search terms used were various combinations of keywords related to the objective such as "physical disability and childbirth", "physically disabled pregnant", "experiences of physically disabled women and childbirth", "perinatal care for physically disabled", "physical disability and parturition", "maternity care and women with disability" and "physical disabilities and perinatal experiences". The records that were included for identification were examined either by their title, abstract or demonstrated keywords.

\section{Inclusion and exclusion criteria}

In this systematic review, we accepted only studies written in English and published between 2016 and February 2021, in order to concentrate the latest available information about this topic. Exclusion criteria were as follows: 1) inability to access the full article text; 2) articles that covered populations of mentally or sensory 
disabled women; and 3) articles that covered fathers, clinicians, physically disabled women that wanted children but had fertility problems, or exclusively pregnant women with physical disabilities who had not given birth yet. Articles that mentioned only cases during the pre- and/or postnatal period as opposed to definite cases based on the time of birth have been also rejected.

These strict criteria were used in order to collect studies that contain factual information about the feelings, thoughts, needs and barriers during delivery from the perspective of women with physical disabilities. Consequently, one of the main criteria that led to inclusion or exclusion of each study was whether it focused on how physically impaired women experience birth.

\section{Findings of the present review}

During the first screening we collected 89 studies, 37 from PubMed and 52 from Google Scholar. After examination, 20 studies were removed as duplicates. From the 69 remaining records, 42 were excluded due to their title and 27 were assessed on the basis of their abstracts. Then, 14 records were dismissed based on their abstract and 13 studies were evaluated based on their full text. Finally, another seven studies were rejected due to non-eligibility and six studies were judged to be appropriate. This process is outlined in Figure 1.

\section{Quality assessment of the reviewed papers}

We conducted a systematic review of the available literature devoted to experiences of physically disabled women during childbirth. The assessment of records was based on the Preferred Reporting Items for Systematic Reviews and Metanalyses (PRISMA) flow diagram. The research was conducted in February 2021 using PubMed and Google Scholar databases. Study titles and abstracts were searched for keywords related to the objective. Articles written in English, published between 01/01/2016 and $01 / 02 / 2021$, were gathered by using every combination of key words. In order to identify as many articles related to the topic as possible, various combinations of the keywords were used for searching in order not to exclude any useful

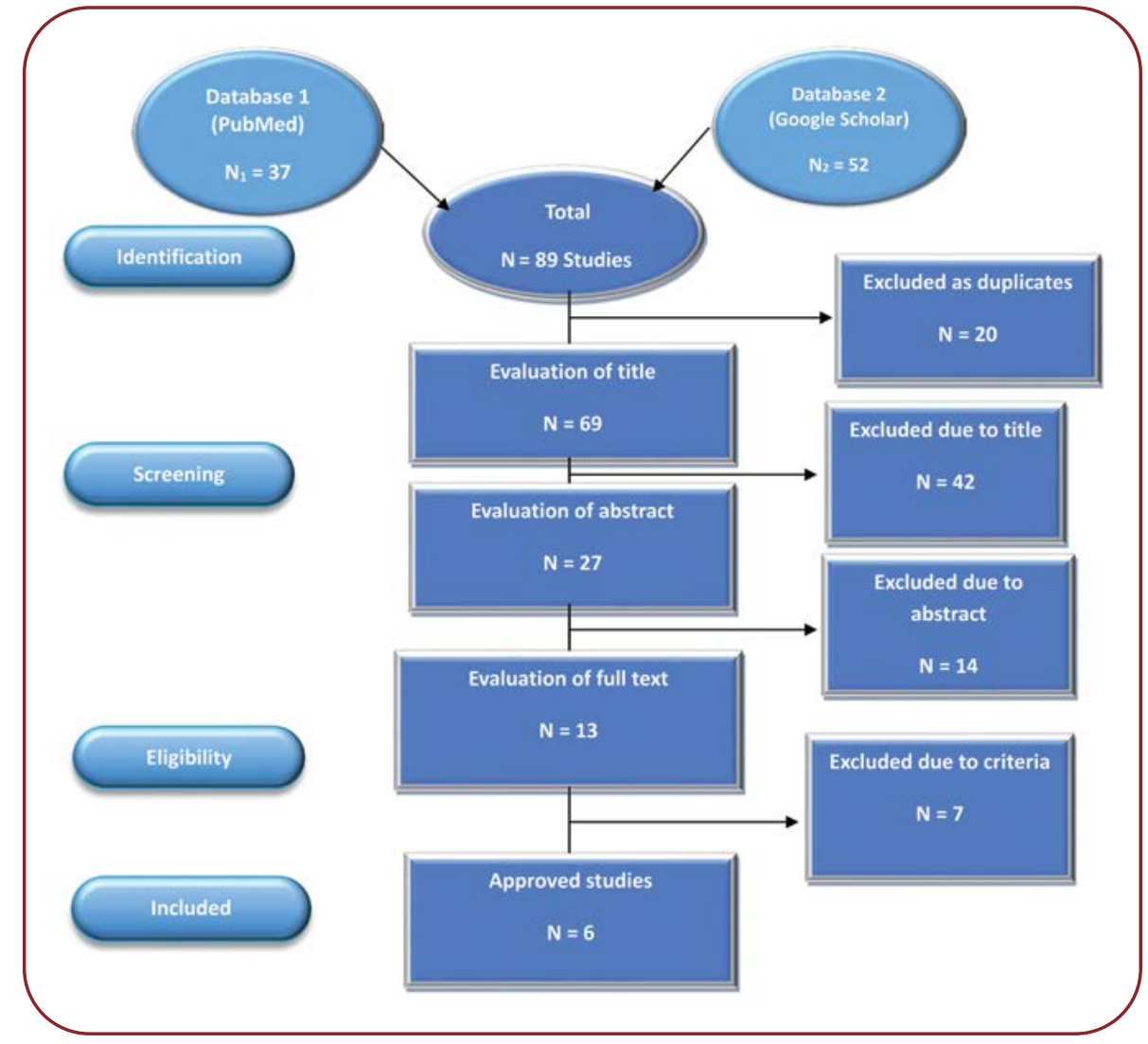

FIGURE 1. Flow chart illustrating the process of article selection 
study. Any study design was accepted. Two criteria were used for the assessment of eligibility of the qualitative framework of the five finally selected studies: 1) Population group (women living with a physical disability, experiencing labour) that reported testimonies relating to their unmet needs, thoughts and feelings during labour; and 2) The survey must show definite and extended reference (at least one-third of the entire article) to experiences of these women at the time of birth.

\section{RESULTS}

$\int$ esc escription of included studies

All six studies that were included in this review present data from developed countries (the United States and Canada) and were written and published in English. The majority of women who were included in all study samples were of childbearing age at the time of interview. Most of them where white, with fewer women of African American (3), Hispanic (3, 6), Asian (4), or other ethnicities. Most of these women were well-educated, married, residents in urban centres, and already had children. Many of them used assistive technology daily in order to mitigate the effects of their conditions. These technologies included scooters, crutches and power wheelchairs. Additionally, some reported that they had their own obstetrician or midwife (3). Regarding the type of delivery, there was no difference between rates of vaginal deliveries and caesarean sections, nor between the type of anaesthesia used (epidural, spinal, general), from those seen in able-bodied women (3). In Table 1, alongside with the characteristics of each study (title, authors, year of publication, aims and methods), we also show some features of study populations such as the mean age of female participants to, inclusion criteria and conclusions.

\section{Analysis of the samples and types of physical disabilities of the studies}

Something that is also crucial and must be highlighted is the types of physical disabilities that these women face and how many are included in each study. As shown in Table 2, cerebral palsy, spinal cord injuries, dwarfism, osteogenesis imperfecta and muscular dystrophy/spinal mus-

TABLE 1. Characteristics of studies in the systematic review

\begin{tabular}{|c|c|c|c|c|c|}
\hline Title & $\begin{array}{c}\text { Authors, } \\
\text { year of } \\
\text { publication }\end{array}$ & Aims & Methods, sample, mean age & Inclusion criteria & Conclusions \\
\hline $\begin{array}{l}\text { Labour, delivery, } \\
\text { and anesthesia } \\
\text { experiences of } \\
\text { women with } \\
\text { physical disability } \\
\text { (Study 1) }\end{array}$ & $\begin{array}{l}\text { Authors: } \\
\text { Suzanne C. } \\
\text { Smeltzer, } \\
\text { Amy J. Wint, } \\
\text { Jeffrey L. } \\
\text { Ecker, Lisa I. } \\
\text { lezzoni, } 2017 .\end{array}$ & $\begin{array}{l}\text { Aims: Exploration of } \\
\text { experiences of the } \\
\text { labour, delivery and } \\
\text { anaesthesia process } \\
\text { of physically disabled } \\
\text { women }\end{array}$ & $\begin{array}{l}\text { Methods: Research on media } \\
\text { sites for people with } \\
\text { disabilities and telephone } \\
\text { review } \\
\mathrm{N}=22 \\
\text { Age: } 34.8 \pm 5.3 \text { years }\end{array}$ & $\begin{array}{l}\text { Women with physical } \\
\text { disabilities from the } \\
\text { United States who had } \\
\text { experienced delivery of } \\
\text { their newborns within } \\
\text { the last } 10 \text { years and } \\
\text { used mobility assistive } \\
\text { technology or had } \\
\text { limited arm or hand } \\
\text { movement at the time } \\
\text { of pregnancy }\end{array}$ & $\begin{array}{l}\text { The responses of women in this study } \\
\text { suggest that there is need to make } \\
\text { intrapartum care better for women with } \\
\text { physical disabilities and to improve their } \\
\text { experiences with labour, birth, and } \\
\text { obstetric anaesthesia care. }\end{array}$ \\
\hline $\begin{array}{l}\text { "We don't know. } \\
\text { We've never had } \\
\text { anybody like you } \\
\text { before": Barriers } \\
\text { to perinatal care } \\
\text { for women with } \\
\text { physical disabilities } \\
\text { (Study 2) }\end{array}$ & $\begin{array}{l}\text { Authors: } \\
\text { Lesley A. } \\
\text { Tarasoff, } 2017\end{array}$ & $\begin{array}{l}\text { Aim: To investigate } \\
\text { perinatal experiences } \\
\text { of women with } \\
\text { physical disabilities } \\
\text { in Ontario, especially } \\
\text { the barriers that they } \\
\text { encounter during } \\
\text { labour }\end{array}$ & $\begin{array}{l}\text { Methods: Participant } \\
\text { recruitment through } \\
\text { organisations, sites and posted } \\
\text { brochures on high risk birth } \\
\text { units and follow-up } \\
\text { interviews. Records were } \\
\text { transcribed verbatim and } \\
\text { decoded. } \\
\mathrm{N}=13 \\
\text { Age: } 36.5 \text { years (range } 26-44)\end{array}$ & $\begin{array}{l}\text { Women with physical } \\
\text { or mobility-limiting } \\
\text { disabilities, who live in } \\
\text { Ontario, are aged } \\
18 \text { years or older, had } \\
\text { experienced labour } \\
\text { within the prior five } \\
\text { years and were able to } \\
\text { communicate in } \\
\text { English. }\end{array}$ & $\begin{array}{l}\text { Study findings reveal that the perinatal } \\
\text { care system is not set up with women } \\
\text { with physical disabilities in mind and } \\
\text { that barriers to perinatal care may } \\
\text { contribute to poor outcomes. } \\
\text { Collabouration among perinatal and } \\
\text { disability-related providers and } \\
\text { meaningful inclusion of women with } \\
\text { physical disabilities in educational } \\
\text { initiatives and care plans are vital to } \\
\text { improve care experiences and outcomes. }\end{array}$ \\
\hline
\end{tabular}

Continued on next page 
Continued from previous page

\begin{tabular}{|c|c|c|c|c|c|}
\hline $\begin{array}{l}\text { Experiences and } \\
\text { unmet needs of } \\
\text { women with } \\
\text { physical disabilities } \\
\text { for pain relief } \\
\text { during labour and } \\
\text { delivery } \\
\text { (Study 3) }\end{array}$ & \begin{tabular}{|l} 
Authors: \\
Linda \\
Long-Bellil, \\
Monika Mitra, \\
Lisa I. \\
Iezzoni, \\
Suzanne C. \\
Smeltzer, \\
Lauren D. \\
Smith, 2017
\end{tabular} & $\begin{array}{l}\text { Aims: To analyse the } \\
\text { experiences of } \\
\text { physically disabled } \\
\text { women with regards } \\
\text { to childbirth and pain } \\
\text { relief in labour, } \\
\text { aiming to the enrich } \\
\text { the knowledge related } \\
\text { to this theme. }\end{array}$ & $\begin{array}{l}\text { Methods: Informative } \\
\text { elements were gathered by } \\
\text { another mixed-methods study } \\
\text { that explored the objective, } \\
\text { and then an interview guide } \\
\text { was created, according to } \\
\text { which the sample was } \\
\text { examined using Atlas TI. } \\
\mathbf{N}=25 \\
\text { Age: } 21 \text { to } 36+\text { (mean age at } \\
\text { birth of youngest child was } \\
32 \text { years) }\end{array}$ & $\begin{array}{l}\text { Women with physical } \\
\text { disabilities or limitation } \\
\text { of movement and use } \\
\text { of their hands and arms } \\
\text { during pregnancy, who } \\
\text { had experienced labour } \\
\text { within the prior } \\
10 \text { years, and were } \\
\text { aged } 55 \text { or younger at } \\
\text { the time of review. }\end{array}$ & $\begin{array}{l}\text { Advanced, individualized planning and } \\
\text { evaluation of their options for pain relief } \\
\text { was most satisfying to women and } \\
\text { enabled them to make an informed } \\
\text { choice. This approach is consistent with } \\
\text { the recommendations of clinicians who } \\
\text { have successfully provided pain relief } \\
\text { during labour to women with complex } \\
\text { physical disabilities. Clinicians who have } \\
\text { successfully delivered babies of women } \\
\text { with these and similar disabilities } \\
\text { emphasize the importance of a team } \\
\text { approach where the anaesthesiologist and } \\
\text { other specialists are involved early in a } \\
\text { woman's care. }\end{array}$ \\
\hline $\begin{array}{l}\text { The impact of } \\
\text { physical disability } \\
\text { on pregnancy and } \\
\text { childbirth } \\
\text { (Study 4) }\end{array}$ & \begin{tabular}{|l} 
Authors: \\
Linda \\
Long-Bellil, \\
Monika Mitra, \\
Lisa I. Iezzoni, \\
Suzanne C. \\
Smeltzer, \\
Lauren D. \\
Smith, 2017
\end{tabular} & $\begin{array}{l}\text { Aims: To define the } \\
\text { possible interactions } \\
\text { between women's } \\
\text { physical disabilities } \\
\text { and their health and } \\
\text { functionality during } \\
\text { pregnancy and } \\
\text { childbirth }\end{array}$ & $\begin{array}{l}\text { Methods: Data was taken } \\
\text { from a larger mixed-methods } \\
\text { study related to the objective } \\
\text { and then interviews were } \\
\text { conducted using a created } \\
\text { guide and analysed using } \\
\text { Atlas TI. } \\
\mathrm{N}=25 \\
\text { Age: } 21 \text { to } 36+\text { (mean age at } \\
\text { birth of youngest child was } \\
32 \text { years). }\end{array}$ & $\begin{array}{l}\text { Women with a physical } \\
\text { disability or another } \\
\text { condition that meant } \\
\text { that they were unable } \\
\text { to walk or use their } \\
\text { arms or hands, that had } \\
\text { experienced labour } \\
\text { within the last } 10 \text { years, } \\
\text { and were } 55 \text { years old } \\
\text { or younger at the time } \\
\text { of the interview. }\end{array}$ & $\begin{array}{l}\text { The importance of advanced planning } \\
\text { and the utility of involving clinicians } \\
\text { with disability-related expertise suggest } \\
\text { that the use of integrated, } \\
\text { interdisciplinary team approaches could } \\
\text { promote quality care by facilitating } \\
\text { improved planning and management. }\end{array}$ \\
\hline $\begin{array}{l}\text { Perinatal } \\
\text { experiences of } \\
\text { women with } \\
\text { physical disabilities } \\
\text { and their } \\
\text { recommendations } \\
\text { for clinicians } \\
\text { (Study 5) }\end{array}$ & $\begin{array}{l}\text { Authors: } \\
\text { Suzanne C. } \\
\text { Smeltzer, } \\
\text { Monika Mitra, } \\
\text { Lisa I. lezzoni, } \\
\text { Linda Long- } \\
\text { Bellil, and } \\
\text { Lauren D. } \\
\text { Smith, } 2016\end{array}$ & $\begin{array}{l}\text { Aims: To explore the } \\
\text { perinatal experiences } \\
\text { of women with } \\
\text { physical disabilities } \\
\text { and record their } \\
\text { recommendations for } \\
\text { clinicians about } \\
\text { improvement of care } \\
\text { for similar cases. }\end{array}$ & $\begin{array}{l}\text { Methods: Participants } \\
\text { identified through emails, } \\
\text { web, social media, blogs and } \\
\text { organisations related to the } \\
\text { desired population, followed } \\
\text { by telephone interviews, } \\
\text { transcription and analysis } \\
\text { using Atlas TI. } \\
\mathrm{N}=25 \\
\text { Age: Age at first child birth } \\
\text { was } 37.4 \pm 7.0 \text { years }\end{array}$ & $\begin{array}{l}\text { Report of physical } \\
\text { disability or limited } \\
\text { ability to walk without } \\
\text { help or use the arms or } \\
\text { hands during the period } \\
\text { of pregnancy, which } \\
\text { occurred within the } \\
\text { prior } 10 \text { years, and } \\
\text { aged from } 21 \text { to } \\
55 \text { years old during the } \\
\text { interview progress. }\end{array}$ & $\begin{array}{l}\text { Participants experienced problematic } \\
\text { interactions with clinicians related to } \\
\text { pregnancy and identified } \\
\text { recommendations for maternity care } \\
\text { clinicians to address those problems with } \\
\text { the goal of improving perinatal health } \\
\text { care for WWPD. }\end{array}$ \\
\hline $\begin{array}{l}\text { Pregnancy among } \\
\text { women with } \\
\text { physical } \\
\text { disabilities: unmet } \\
\text { needs and } \\
\text { recommendations } \\
\text { on navigating } \\
\text { pregnancy } \\
\text { (Study 6) }\end{array}$ & $\begin{array}{l}\text { Authors: } \\
\text { Monica Mitra, } \\
\text { Linda M } \\
\text { Long-Bellil, } \\
\text { Suzanne C } \\
\text { Smltzer, } \\
\text { Lauren D } \\
\text { Smith, } 2016\end{array}$ & $\begin{array}{l}\text { Aim: In-depth } \\
\text { examination of unmet } \\
\text { health care needs } \\
\text { during and around the } \\
\text { time of pregnancy } \\
\text { among a sample of } \\
\text { women with physical } \\
\text { disabilities. It also } \\
\text { offers } \\
\text { recommendations to } \\
\text { other women with } \\
\text { physical disabilities } \\
\text { who are considering } \\
\text { pregnancy }\end{array}$ & $\begin{array}{l}\text { Methods: Individual semi- } \\
\text { structured qualitative phone } \\
\text { interviews were conducted } \\
\text { with women with physical } \\
\text { disabilities from across the } \\
\text { United States who had a baby } \\
\text { in the past } 10 \text { years. } \\
\mathrm{N}: 25 \\
\text { Age: The average age of the } \\
\text { women at the time of the } \\
\text { youngest child's birth was } 32 .\end{array}$ & $\begin{array}{l}\text { To be eligible, a } \\
\text { woman should have } \\
\text { had a physical } \\
\text { disability or health } \\
\text { condition that affected } \\
\text { her ability to walk or to } \\
\text { use her arms or hands } \\
\text { at the time of her } \\
\text { pregnancy, had } \\
\text { delivered a child within } \\
\text { the last } 10 \text { years, and } \\
\text { be age } 55 \text { or younger at } \\
\text { the time of the } \\
\text { interview }\end{array}$ & $\begin{array}{l}\text { Study results highlight unmet needs for } \\
\text { care, information, and support during } \\
\text { pregnancy and at postpartum. The lack of } \\
\text { clinician knowledge and training put } \\
\text { women with physical disabilities at risk } \\
\text { of receiving inaccurate or inappropriate } \\
\text { advice about the risks and potential } \\
\text { complications of pregnancy and also } \\
\text { creates challenges during the actual } \\
\text { process of childbirth, such as the choice } \\
\text { of the method of delivery and anesthesia } \\
\text { with regard to risks that may arise during } \\
\text { the childbirth process. }\end{array}$ \\
\hline
\end{tabular}


cular atrophy are the most common disabilities in these women.

\section{Findings and conclusions of each study}

Many women did not face any significant problems or felt secure during their labour and delivery experience. Nevertheless, others faced adverse conditions during this important time. Findings for each study are discussed individually below.

Study 1 - After analysis of the records, results focused on two areas: 1) labour and birth experience; and 2) obstetrical anaesthesia. The first area comprised four subthemes, including: a) women's preferences for type of delivery; b) clinicians and women that expected no labour pain; c) fears prompting active advocacy; and d) positive experiences. The second area also comprised four themes: a) importance of consultation with the anaesthesia team; b) decisions about epidural/spinal vs general anaesthesia; c) failed epidural after repeated efforts; and d) fear of injury related to anaesthesia. This study conclusively demonstrated that the needs of women with disabilities undergoing the transition to maternity focused on higher quality of consultancy about the obstetrical techniques used during childbirth, substantial communication with clinicians and staff, and improvement regarding knowledge and technical skills (3).

Study 2 - The results of the research showed the following issues reported by women: 1 ) inaccessible care settings; 2) negative attitudes; 3) lack of knowledge and experience; 4) lack of communication and collaboration among providers; and 5) misunderstandings of disability and disability-related needs. The final issue proved to be the foremost consideration of women. The study concluded that the issue was not only the lack of knowledge and special facilities but also the need for healthcare workers to learning how to serve this patient population during transition to maternity with more respect, devotion and professionalism (4).

Study 3 - The results of the study indicate various major issues that arise: 1) women's preferences for method of pain relief; 2) recognition of implications of disability for labour and delivery; 3 ) choosing between pain relief options; 4) deficiency in clinician knowledge; and 5) planning ahead regarding women's care. The research showed that most women were well in- formed about pain relief and had a positive experience of labour. Nevertheless, clinicians' lack of training and knowledge about the individualised management of each labour and non-existent individualised expert care teams for planning ahead are some of the most important barriers that women with physical disabilities face during childbirth. Last but not least, types of pain relief must also be individualised, depending on the type of disability in each case (5).

Study 4 - The results were focused on how physically disabling conditions were affecting pregnancy, labour and delivery (with regards to the type of delivery, anaesthesia and care), and the maternal and infant outcomes after pregnancy and delivery and mediating factors that can lead to positive outcomes. Women reported that their physical disabilities did not have a serious impact on their pregnancy and childbirth. In addition, most of them reported that they had a positive experience during labour and were satisfied with the mode of delivery, despite facing some challenges. This study emphasised that, through advanced planning and collaboration between expert clinicians, both positive labour experiences and positive maternal and infant outcomes were achieved (6).

Study 5 - The results referred to three primary issues: 1) clinicians' lack of knowledge about the pregnancy-related needs of women with physical disabilities (WWPD); 2) clinicians' failure to consider women's knowledge, experience, and expertise about their own disabilities; and 3) clinicians' lack of awareness of the reproductive concerns of WWPD. In conclusion, it appeared that some WWPD had positive care experiences. Nevertheless, the great majority of women experienced insufficient care and attitudes. Additionally, this study has not only shown the great deficiency that was observed in clinicians' knowledge about medical management of women with physical disabilities, but it has also identified stereotyped viewpoints about this patient population. In conclusion, this study reports recommendations from women to healthcare professionals (7).

Study 6 - Data analysis revealed three broad themes related to unmet needs during pregnancy and childbirth among women with physical disabilities, including (1) clinician knowledge and attitudes; (2) physical accessibility of health care facilities and equipment; and (3) need for 
TA B LE 2. Disabilities

\begin{tabular}{|c|c|c|c|c|c|c|}
\hline Condition & N1 & N2 & N3 & N4 & N5* & N6 \\
\hline Cerebral palsy & 4 & 4 & 3 & 3 & + & + \\
\hline Osteogenesis imperfecta (OI) & 1 & & 4 & 4 & + & + \\
\hline Spinal cord injury & 8 & 1 & 2 & 2 & + & + \\
\hline Multiple sclerosis (MS) & & & 1 & 1 & + & + \\
\hline Amputation (congenital or not) & & 1 & 2 & 2 & + & + \\
\hline Dwarfism & & & 5 & 5 & + & + \\
\hline Muscular dystrophy/spinal muscular atrophy & & 1 & 5 & 5 & + & + \\
\hline Congenital bone growth disorder & & 1 & & & & \\
\hline Degenerative disc disease & & 1 & & & & \\
\hline Osteoporosis & & 1 & & & & \\
\hline Scoliosis & & 1 & & & & \\
\hline Arthritic condition & & 3 & & & & \\
\hline Spina bifida & 1 & & 1 & 1 & + & + \\
\hline Congenital missing $3 / 4$ limbs & 1 & & & & & \\
\hline Multiple bone injuries from car crash & 1 & & & & & \\
\hline Arthrogryposis & 2 & & & & & \\
\hline Congenital myasthenia & 1 & & & & & \\
\hline Ataxia/neuropathy & 1 & & & & & \\
\hline Charcot-Marie-Tooth & 1 & & & & & \\
\hline Fibromyalgia & & 1 & & & & \\
\hline Stroke & & & 2 & 2 & & \\
\hline Other form of disability ${ }^{\mathrm{a}} /$ More than one condition ${ }^{\mathrm{b}}$ & 1 & 1 & & & & \\
\hline
\end{tabular}

*Study 5 does not mention how many women live with each condition, with only disabling conditions being reported.

aB Blindness for Study 2.

'Incomplete spinal cord injury and mitochondrial disease.

information related to pregnancy and postpartum supports. This study confirmed that the lack of clinician knowledge and training continues to put women with physical disabilities at risk of receiving inaccurate or inappropriate advice about the risks and potential complications of pregnancy. These risks can lead to difficulty in making informed decisions and presents challenges to appropriate perinatal care for physically disabled women (8).

\section{DISCUSSION}

The aim of this review was to present some of the usual experiences, thoughts, feelings, concerns and barriers that women with physical disabilities face during childbirth. All of the above-mentioned ones are defined by the psy- chology that women generally have at the time of delivery. This is a delicate issue, as the period of a woman's transition to motherhood is vital; it can effectively determine the characteristics of their role as mothers for the rest of their lives and consequently their children's lives too $(9,10)$. We must consider that, while women who live without health problems confront issues like these, those with physical disabilities may encounter even more difficulties. For these reasons, medical staff ought to manage this process with more dexterity and advanced care in women living with disabling conditions. The findings of this review conclude that the components affecting women during labour referred to both the women themselves, maternity care providers and medical facilities. The main factors included 
1) the selection of type of delivery; 2) anaesthesia (types, fear of injury and failed implementation of epidural type); 3) deficiency in knowledge and experience with regards to each woman's disabling condition; 4) negative attitudes from clinicians (deficient empathy and limited respect);5) inadequate levels of collaboration between health professionals working in different healthcare settings; 6) absence of a birth plan; and 7) inaccessibility to facilities and care equipment.

Regarding the type of delivery, this is a crucial theme that is generally met in maternity hospitals. Impairment in a woman's body structure or function is a significant reason why only few women with disabilities are able to choose a comfortable position during labour versus non-disabled women, and for some disabled women this may not be possible at all (11). Given that some types of physical disability cause a body with certain limitations for the task of labour, the decision between the options of natural birth and caesarean section is controversial. According to Smeltzer et al (3), women have differing opinions. Some of them reported that a caesarean section would be the perfect way to prevent a possible episiotomy or tear, avoiding having to care for the wound afterwards, which may be more challenging for a disabled person. Additionally, some women preferred caesarean section as labour may put them at increased the risk of autonomic dysreflexia, a condition that is connected with acute rises in blood pressure in people with spinal cord injuries that involve the thoracic nerves of the spine or above (12). On the other hand, there are women who desire to experience the unique experience of natural birth, especially considering that disabled people may have experienced many medical interventions throughout their lives and this could be an opportunity to participate in a completely natural process, if this is practically feasible. Furthermore, some women reported that they would like to be alert during the period after birth, in order to be able to hold their baby without waiting for prolonged recovery (3). Additionally, the fact that there may be abdominal adhesions due to previous surgeries relating to their disability may be another disadvantage of a caesarean section (6).

The anaesthesia process was another matter of concern for women. They agreed that, through accurate consultation with clinicians, they could make the right choice regarding the type of anaesthesia (epidural/spinal or general) and have extremely positive outcomes. However, it was also stated that many health practitioners either did not have the appropriate knowledge to effectively manage some cases, or they were not willing to provide intensive care and attention to these women $(3,5,6)$. Furthermore, many women had already done their own research about their options $(3,5)$, and some reported that their preferences about the type of pain relief were completely ignored by anaesthesia practitioners. In addition, there were experiences of repeated failed efforts in establishing epidural anaesthesia, which led to feelings of fear, as some women also feared being paralysed after anaesthesia due to their lack of knowledge of the extreme rarity of this complication (3). One woman stated that she desired to undergo labour naturally without using medicine and experience it to the fullest, as able-bodied mothers are able to. There were also women that rejected general anaesthesia because they wanted to be awake and have their partner next to them, experiencing this important time together (5). The foremost challenge that these women encounter regarding anaesthesia is that every type of physical disability needs to be examined for limitations. For example, a woman with spinal cord injury above T6 (thoracic 6) must be prompted to choose the epidural type of anaesthesia to prevent the initiation of autonomic dysreflexia (6).

Knowledge about every single case of physical disability, its limitations, characteristics, and how it affects labour must be acquired by health professionals. Through enriched education, the clinicians' ability to respond to women's needs will advance. Not only will this improve them as professionals and make them feel more competent, but it is also an opportunity to improve their relationships with disabled women. It is likely that women will appreciate clinicians' appropriate care and consultation, mitigating their insecurities and fears.

Women recommended that, alongside the need for extra education surrounding cases of female patients with disabilities, health professionals must cultivate and increase their empathy and respect towards physically disabled mothers. This is dependent on each person's subjective characteristics and changing attitudes 
may be a difficult task. Nevertheless, health practitioners ought to be thought of as humans first, as this type of profession involves people who face special difficulties and need special care and support. Last but not least, this will require devotion and respect in order to offer maternity services appropriately and have positive perinatal outcomes. Healthcare professionals, especially midwives, should focus more on women's abilities than disabilities and offer them optimum care and communication to empower the disabled pregnant women (13).

Furthermore, collaboration between clinicians from different healthcare settings was highlighted as an issue in terms of creating a secure environment for women and achieving positive birth, maternal and neonatal outcomes. Productive cooperation must be achieved within the medical staff. If this component can be improved, it will be easier to care for these women and their needs, and tackle the possible complications effectively. Women will also feel safer and they will be more compliant during the delivery procedure.

In addition, the absence of a birth plan was reported to be another difficulty that women with disabilities face during childbirth. Medical and midwifery staff ought to accommodate the planning of the whole process of delivery, including all possible complications and responses of women's bodies. They must describe the process of birth, mentioning the duration of each stage and describing the expected physical changes and responses of their body. If this component is missed, women may feel insecure and unable to appropriately coordinate their actions during delivery.

The final but significant problem that must be solved is the inaccessibility of facilities and inadequate equipment of hospitals. Even if clinicians are extremely competent, without the appropriate devices and adapted facilities such as bathrooms and beds, the management of these women will be an impossible task for both clinicians and women.

\section{CONCLUSION}

The number of women with disabilities is rising and may have an equal desire to parenthood as other able-bodied women. In essence, women with physical disabilities who are going to be mothers are just like all other mothers-to-be. They have the same questions, rights, thoughts, feelings and expectations that every non-disabled woman has about their childbirth. Nevertheless, the confrontation they experience regarding their special needs and worries about their disabling condition is something that, unfortunately, medical facilities are not currently addressing sufficiently. We observed that these women face discouraging situations that distract them from their objective to have a positive birth experience. Lack of guidance and knowledge, and inexperience regarding the selection of birth type, anaesthesia and management of disabling conditions' special needs, unfavourable behaviours of clinicians, insufficient cooperation between healthcare settings, absence of potential of birth planning, and inadequate medical premises and supplies complicate the transition to motherhood and the achievement of positive birth results. Consequently, health care professionals are called to overcome the obstacles that prevent them from managing these cases appropriately, through the suggested reading of new studies and further research. Finally, we highlight that a change in their attitudes, approaching women's care holistically and with respect, welcome their legitimate claim to be parents, provide care and support them through their pregnancies and the adequacy of appropriate medical equipment and facilities, are crucial components that must be provided, in order to offer excellent care from both a scientific and a human perspective.

Conflicts of interest: none declared.

Financial support: none declared.

\section{R eferences}

1. Centers for Disease Control and Prevention (C.D.C.) (2020). Disability and Health Overview. Retrieved from https://www.cdc.gov/ncbddd/ disabilityandhealth/disability.html. Accessed April 2021.

2. Handicaps Welfare Association (H.W.A.) (2021). General Information on Physical
Disabilities. Retrieved from https://hwa.org.sg/general-informationon-physical-disabilities/. Accessed April 2021. 
3. Smeltzer SC, Wint AJ, Ecker JL, Iezzoni LI. Labour, delivery, and anesthesia experiences of women with physical disability.

Birth Issues in Perinatal Health 2017;44:315-324.

4. Tarasoff LA. “We don't know. We've never had anybody like you before": Barriers to perinatal care for women with physical disabilities. Disability and Health Journal 2017;10:426-433.

5. Long-Bellil L, Mitra M, Iezzoni LI, et al. Experiences and unmet needs of women with physical disabilities for pain relief during labour and delivery. Disability and Health Journal 2017;10:440-444.

6. Long-Bellil L, Mitra M, Iezzoni LI, et al. The impact of physical disability on pregnancy and childbirth.

Journal of Women's Health 2017;26:878-885.

7. Smeltzer SC, Mitra M, Iezzoni LI, et al.

Perinatal experiences of women with physical disabilities and their recommendations for clinicians. Journal of obstetric, gynecologic, and neonatal nursing: JOGNN 2016;45:781-789.

8. Mitra M, Long-Bellil LM, Iezzoni LI et al. Pregnancy among women with physical disabilities: Unmet needs and recommendations on navigating pregnancy.

Disabil Health J 2016;9:457-463.

9. Mangeli M, Rayyani M, Cheraghi MA, Tirgari B. Exploring the Challenges of Adolescent Mothers From Their Life Experiences in the Transition to Motherhood: A Qualitative Study. J Family Reprod Health 2017;11:165-173.
10. McLeish J, Redshaw M. Mothers' accounts of the impact on emotional wellbeing of organised peer support in pregnancy and early parenthood: a qualitative study.

BMC Pregnancy and Childbirth 2017;17:28.

11. Redshaw M, Malouf R, Gao H, Gray R. Women with disability: the experience of maternity care during pregnancy, labour and birth and the postnatal period. BMC Pregnancy and Childbirth 2013;13:174.

12. Health Link British Columbia (H.L.B.C.) (2019). Spinal Cord Injury: Autonomic Dyreflexia. Retrieved from https://www. healthlinkbc.ca/health-topics/ug2980 Accessed April 2021

13. Smeltzer SC. Pregnancy in Women With Physical Disabilities. Journal of Obstetric, Gynecologic, and Neonatal Nursing: JOGNN 2007;36:88-96. 